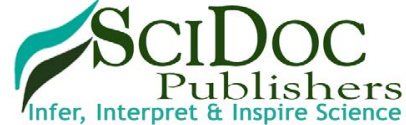

International Journal of Microbiology \& Advanced Immunology (IJMAI) ISSN:2329-9967

\title{
Lymphocyte Subset (CD3, CD4 and CD8 Cells) and their Ratios in HIV patients on Highly Active Antiretroviral Therapy (HAART) and HAART Naïve Patients
}

Research Article

Wiredu $\mathrm{OK}^{1}$, Edzeamey $\mathrm{FJ}^{1 *}$, Dompreh $\mathrm{A}^{2}$, Awuah $\mathrm{M}^{3}$, Ako AK ${ }^{4}$, Sampong BB ${ }^{1}$, Ahmed $\mathrm{S}^{1}$, Yeboah $\mathrm{EK}^{5}$

${ }^{1}$ Laboratory Department, Ashanti- Bekwai Municipal Hospital, Ashanti-Bekwai, Ghana.

${ }^{2}$ Serology Department, Komfo Anokye Teaching Hospital, Kumasi, Ghana.

${ }^{3}$ Department of Medical Laboratory Technology, School of Allied Health Sciences, University of Cape Coast, Ghana.

${ }^{4}$ Department of Biomedical Sciences, School of Allied Health Sciences, University of Cape Coast, Ghana.

${ }^{5}$ Laboratory Department, Asokwa Childrens' Hospital, Kumasi, Ghana.

\section{Abstract}

Background: Lymphocytes form part of blood cells involve in the fight against infection in the immune system. These cells are mostly implicated in the pathogenesis of HIV/AIDS.

Objective: This study sought to determine the lymphocyte differentials in seropositive HIV patients on HAART and HAART naive.

Materials and Methods: This was a hospital-based, case control study conducted among 150 participants. HIV patients' on HAART $(n=50)$ and HAART naïve HIV $(n=50)$ patients and the control group $(n=50)$ was HIV Seronegative individuals. Venous blood was drawn from each of the participant into K3 EDTA tubes. Becton Dickinson (BD) FACS Count system (Becton, Dickinson and Company, California, USA) was used to determine the lymphocyte differentials (CD3, CD4 and CD8).

Results: The study observed an average CD3 of $1867 \pm 99.72$ cells $/ \mathrm{mm}^{3}, 1639 \pm 96.56$ cells $/ \mathrm{mm}^{3}$ and $1755 \pm 139.3$ cells/ $\mathrm{mm}^{3}$ in the control, on HAART and HAART naïve groups respectively, CD4 of $1084 \pm 55.40 \mathrm{cells} / \mathrm{mm}^{3}, 498.5 \pm 43.85$ cells $/ \mathrm{mm}^{3}$, and $506.7 \pm 60.58$ cells $/ \mathrm{mm}^{3}$ in the control, on HAART and HAART naïve groups respectively and CD8 of $662.0 \pm 45.84$ cells $/ \mathrm{mm}^{3}, 1091 \pm 74.81$ cells $/ \mathrm{mm}^{3}$ and $1210 \pm 125.3 \mathrm{cells} / \mathrm{mm}^{3}$ in the control, on HAART and HAART naïve groups respectively.

Conclusion: The pathogenic effect of HIV virus resulted in significantly low mean levels of CD4, CD8, CD4/CD3 and CD4/CD8 ratio among on HAART and HAART naïve patients compared to control group.

Keywords: Lymphocyte Subset; HAART; HAART Naïve; HIV Patients; Seropositive; CD4+; CD8+.

Abbreviations: HAART: Highly Active Antiretroviral Therapy; BD: Becton Dickinson; CD: Cluster of Differentiation; KATH: Komfo Anokye Teaching Hospital; SPSS: Statistical Package for Social Scientist.

\section{Introduction}

Lymphocytes form part of the blood cells involve in the fight against infection in the immune system. They function in the adaptive immunity where the B-lymphocyte functions under the humoral immunity and the T-lymphocyte functions under the cell-mediated immunity which is involve in the defence against intracellular microbes. The latter is further classified as CD4+ and $\mathrm{CD} 8+$ with the CD standing for Cluster of Differentiation. These are the cells which are mostly implicated in the pathogenesis of HIV/AIDS. However, diverse effect is observed following their activation. The presence of HIV in the host cell induces response which culminates into immune activation. Immune activation though important for host in wading effective immune response against HIV, its repeated occurrence creates an oxides environment for the virus to replicate [1]. Active molecular and cellular processes are among the several events that characterize immune activation in HIV patient.

\author{
*Corresponding Author: \\ Fred Jonathan Edzeamey, \\ Laboratory Department, Ashanti-Bekwai Municipal Hospital, Ashanti-Bekwai, Ghana. \\ Tel: +233241652612 \\ Email: kwesi.mkk@gmail.com \\ Received: May 08, 2018 \\ Accepted: May 25, 2018 \\ Published: May 28, 2018
}

Citation: Wiredu OK, Edzeamey FJ, Dompreh A, Awuah M, Ako AK, Sampong BB, et al., Lymphocyte Subset (CD3, CD4 and CD8 Cells) and their Ratios in HIV patients on Highly Active Antiretroviral Therapy (HAART) and HAART Naive Patients. Int J Microbiol Adv Immunol. 2018;6(2):92-95. doi: http://dx.doi.org/10.19070/2329-9967-1800018

Copyright: Edzeamey $\mathbf{F J}^{\circ}$ 2018. This is an open-access article distributed under the terms of the Creative Commons Attribution License, which permits unrestricted use, distribution and reproduction in any medium, provided the original author and source are credited. 
During the early stage of HIV infection a lot of people initiate an effective immune response but it becomes ineffective over time. CD4 and CD8 T cells form the pillar of cellular response while humoral response involves the antibody production and its related activities [2]. CD8 T cells exercise its cytotoxic effect on the virus as well as secrete some chemokines during the primary stage of HIV infection. Some HIV patient are able to maintain high level of $\mathrm{CD} 8+$ specific $\mathrm{T}$ cell which control viral replication but it falls after infection in most patients. CD8 $\mathrm{T}$ cells can therefore be used to ascertain pathogenesis in HIV infected persons. Clinical studies conducted by Golgi and colleagues concluded that excessive immune activation leads to immune dysfunction in chronic HIV patients. The findings showed that CD38 a maker of CD8 $\mathrm{T}$ cell and HLA-DR expression negatively correlate better with the worse condition of HIV infected persons than viral load [3-5]. So as CD4+ T-cell numbers decrease in HIV condition, HLA-DR+ and CD38+ CD8+ T lymphocytes rather appreciate in numbers [5]. Further studies has also established that viral load cannot separately determine the rate of progression to AIDS, and that immune activation better reflects variations in CD4+ T-cell stronger and independent of viral load [6-9].

The survival rate of HIV patient is closely related to the levels of activated CD8 $+\mathrm{T}$ cells than CD4+ $\mathrm{T}$ cells or viral load [5] and high viremia in some HIV patient is not an indication of HIV pathogenesis $[10,11]$. Immune activation is highly related to high incidence of diseases and death in successfully HAARTtreated patients with undetectable viremia [12]. Certain stage of infection records complete absence CD4+ $\mathrm{T}$ cells both in the lymphoid and circulation sites. At this stage the infected HIV individual starts experiencing AIDS condition [13]. AIDS ushers the gradual breakdown of the immune status as a result of the reduced level of CD4 T cell and high levels of inflammatory cytokines which suppresses other immune cells from replenishing lost ones. Contrarily to CD4+ T cell, CD8+ T-cell rather increase in their numbers due to the expansion of memory $\mathrm{CD} 8+\mathrm{T}$ cells usually HIV-reactive cells during the early stage of HIV infection. Expansion of CD8+ T cell may reduce at the later stage of HIV infection. Although naïve CD8+ T cell may decrease during the beginning of HIV infection, absolute count of CD8 T cells only declines when HIV disease progresses. This therefore makes it expedient to get credible CD4 count results in order to estimate immunity build up and properly manage the health of persons infected with HIV [14]. It is important that clinicians request for CD4 count to be done for HIV infected patients every 3-6 months, so that those with low levels of CD4 count are placed on antiretroviral therapy. Presentation of low absolute CD4 counts and the perturbed high level of cytokines indicates break down of the immune system of HIV patient.

\section{Materials and Methods}

This was a hospital-based, case control study conducted from June to November 2014 in the Komfo Anokye Teaching Hospital (KATH), Kumasi, Ghana. 150 participants in all were recruited for this study. Hundred participants were recruited from the HIV clinic at KATH out of which 50 were on ART and the other 50 participants were treatment naïve. The 50 control group was selected from client visiting the blood bank unit of KATH to make voluntary donation. Whilst HIV patients between 18-45 years, newly diagnosis patient for at most six months for HAART naive, HIV patient on HAART for at most one year and HIV patients without Immunocompromised infection (example Tuberculosis, HCV, HBV) were included in the study, Patients with Haemoglobin levels less than $8 \mathrm{~g} / \mathrm{dl}$ and those having any Immunocompromised infection (example Tuberculosis, HCV, HBV) were excluded from the study. Also, the exclusion criteria for the control group were the same as those of the patients aside being negative for HIV.

\section{Ethical Consideration}

The study protocol was sent for review and approval from the Committee on Human Research, Publications and Ethics, School of Medical Sciences, Kwame Nkrumah University of Science and Technology and Komfo Anokye Teaching Hospital, in Kumasi. Permission was sought from the Head of Diagnostic Directorate to undertake the study at the serology unit of the Komfo Anokye Teaching Hospital.

\section{Sample Collection and Determination of Lymphocyte Differentials}

$3 \mathrm{ml}$ of venous blood was drawn from each of the participant by venepuncture into K3 EDTA vacutainer tube. The immunological markers that were determined were absolute cell counts of CD4, CD8 and CD3 T lymphocytes in unlysed whole blood. The CD4, CD8 and CD3 $T$ lymphocytes counts were determined using the Becton Dickinson (BD) FACS Count system (Becton, Dickinson and Company, California, USA). The CD4 count reagent was inverted up and down for $10 \mathrm{sec}$ in order to suspend the bead and then uncorked with the coring station. After which $50 \mu$ l of the sample (whole blood) was added to the corresponding tube. The mixture was vortexed and incubated at room temperature in the dark for $60-120$ minutes. $50 \mu$ l of the fixative solution was added, caped and incubated for 15 mins. It was then immediately analyzed on the FACS count instrument after vortexing upside down for $5 \mathrm{sec}$. The in-built software then analyze and quantifies the CD4+ lymphocyte, CD8+ lymphocytes, CD4+/ CD8+ ratio and the absolute $\mathrm{CD} 3$ count of each sample.

\section{Statistical Analysis}

The data was analysed using the Statistical Package for Social Scientist (SPSS) Statistical Software (version 17.0, SPSS Inc., Chicago, IL, USA). For all statistical comparisons, the level of significance was set at $\mathrm{p}<0.05$.

\section{Results}

\section{Demographic Characteristics of Study Population}

The mean age of the HIV patients $(38.57 \pm 1.13$ for those on treatment and $37.25 \pm 1.19$ for treatment naive) were significantly higher $(\mathrm{P}<0.0001)$ respectively than that of the controls $(22.35$ \pm 1.03 ). The female participants (42 for those on treatment and 36 for the treatment naïve) far outnumber the male participants ( 8 for on-treatment and 14 for treatment naïve). However for the controls the number of males (37) was almost three times the number of females (13). 


\section{Lymphocyte Subset Analysis for Study Population}

Mean levels of $\mathrm{CD} 8, \mathrm{CD} 4$, and the ratio of $\mathrm{CD} 4 / \mathrm{CD} 8$ were significantly lower among treatment and treatment naïve HIV infected participants compared to control $(p<0.0001)$. Moreover, the ratio of $\mathrm{CD} 4 / \mathrm{CD} 3$ was significantly lower among treatment and treatment naive HIV infected participants compared to control $(\mathrm{p}<0.0001)$ (Table 2) but difference between treatment and treatment naïve was not significant.

\section{Discussion}

The study observed a significant decrease of CD4 $\mathrm{T}$ cell in seropositive HIV studied group compared to seronegative group (Table 1.0). Generally CD4 count in HIV patient have been observed to decline as the disease progresses [1,2] and is a vascular risk factor among HIV-infected individuals [15]. The increased rates of apoptosis within blood lymphocyte subsets in HIV positive individuals [16] could contribute to lower lymphocyte levels. Secondly, the interactions between the virus g120 and the CD4 $\mathrm{T}$ cell of the host cell induce by IFN can result apoptosis of the host cell due to the deleterious effect of the virus activity on the CD4+ T cell [17]. Thirdly the thymosupressive effect of pro-inflammatory cytokines (IL-6) [18] can affect the thymus output. This leads to fibrosis of the lymphatic tissue damaging the architecture and preventing normal $\mathrm{T}$ cell homeostasis [18, 19]. Due to this there is a reduction in the number of new cell that is churns out by the thymus in seropositive HIV patient [13]. The ability of HIV infected patient in replacing lost T cells becomes compromised. As the naïve $T$ cell pool are not been replenished, with time there will not be any $\mathrm{T}$ cell to supplant the old CD8 and CD4 $\mathrm{T}$ cell when they die out. At such situation attack by new strain of the virus receive less resistance from the CD8 $\mathrm{T}$ cells resulting in the reduction in the numbers of the CD4 $\mathrm{T}$ cells.
There was no significant difference between the CD4+ T cell of the On-treatment and treatment naïve group probably because, effective HAART regimes results in similar decay of plasma HIVRNA [20].

There was a significant high level of CD8 $+\mathrm{T}$ cell in seropositive HIV compared to control group (Table 1.0). In HIV infected individuals $\mathrm{CD} 8+$ subset in the blood from site such as the lung are unable to migrate into high endothelia venule-containing lymphoid tissue due to insufficient expression L-selectin homing receptor(s) or an inability to transduce G-protein-associated signals leading to its accumulation in the peripheral blood. CD8+ $\mathrm{T}$ cell are also known to expand more extensively than CD4+ T cells during immune response. This might have accounted for the overall increase in CD8+ $\mathrm{T}$ cell in HIV infected individual. As the blood CD4+ $\mathrm{T}$ cells declines, $\mathrm{CD} 8+\mathrm{T}$ cell levels are either maintained or increased, this will therefore result in CD4/CD8 ratio decreasing in order to maintain homeostatic mechanisms. This trend was consistent with this study results (Table 1) which indicates a significant decrease of $\mathrm{CD} 4 / \mathrm{CD} 8$ ratios of the seropositive HIV group compared to the control group. However, the ratio of $\mathrm{CD} 4 / \mathrm{CD} 3$ was significantly lower among treatment and treatment naïve $\mathrm{HIV}$ infected participants compared to control. The low level of CD4/CD3 exhibit a steady progression of the HIV infection [5,7] and is used to monitor some forms of immunodeficiency [4]. The association between low CD4+ T-cell count may possibly be explained by chronic inflammation in immunosuppressed HIV-infected individuals [21]. Meanwhile there was a significant positive correlation between CD8 $\mathrm{T}$ cell and $\mathrm{CD} 3 \mathrm{~T}$ cells and between the ratio of $\mathrm{CD} 4 / \mathrm{CD} 8$ and the ratio of $\mathrm{CD} 4 / \mathrm{CD} 3$. A significant and negative correlation of CD8 $\mathrm{T}$ cell was observed with the ratio of CD4/CD8 and CD4/ CD3 in all the studied participants.

Table 1. Socio-demographic Characteristics of study Participants.

\begin{tabular}{|c|c|c|c|c|}
\hline & \multirow[b]{2}{*}{ Control $(n=50)$} & \multicolumn{2}{|c|}{ HIV Patients } & \multirow[b]{2}{*}{ P-value } \\
\hline & & On HAART $(n=50)$ & HAART Naïve $(n=50)$ & \\
\hline Age (years) & $22.35 \pm 1.03$ & $38.57 \pm 1.13 \mathrm{H+十}$ & $37.25 \pm 1.19 \mathrm{Ht}$ & $<0.0001$ \\
\hline \multicolumn{5}{|l|}{ Gender n $(\%)$} \\
\hline Male & $37(74.0 \%)$ & $8(16.0 \%)$ & $14(28.0 \%)$ & \\
\hline Female & $13(26.0 \%)$ & $42(84.0 \%)$ & $36(72.0 \%)$ & \\
\hline
\end{tabular}

Table 2. Levels of Lymphocyte Subset in Studied Group.

\begin{tabular}{|c|c|c|c|c|}
\hline & & \multicolumn{2}{|c|}{ HIV Patients } & \multirow[b]{2}{*}{ P-value } \\
\hline & $\begin{array}{l}\text { Control } \\
(n=50)\end{array}$ & $\begin{array}{c}\text { On HAART } \\
(n=50)\end{array}$ & $\begin{array}{l}\text { HAART Naïve } \\
\quad(n=50)\end{array}$ & \\
\hline CD3 (cells $/ \mathrm{mm}^{3}$ ) & $1867 \pm 99.72$ & $1639 \pm 96.56$ & $1755 \pm 139.3$ & 0.3674 \\
\hline CD8 (cells $\left./ \mathrm{mm}^{3}\right)$ & $662.0 \pm 45.84$ & $1091 \pm 74.81 \mathrm{H \dagger}$ & $1210 \pm 125.3+\dagger$ & $<0.0001$ \\
\hline CD4 (cells $\left./ \mathrm{mm}^{3}\right)$ & $1084 \pm 55.40$ & $498.5 \pm 43.85 \mathrm{t+十}$ & $506.7 \pm 60.58 \mathrm{H}+$ & $<0.0001$ \\
\hline $\mathrm{CD} 4 / \mathrm{CD} 3$ & $0.59 \pm 0.01$ & $0.30 \pm 0.02 \mathrm{t+}$ & $0.28 \pm 0.03 \mathrm{H+}$ & $<0.0001$ \\
\hline $\mathrm{CD} 4 / \mathrm{CD} 8$ & $1.73 \pm 0.06$ & $0.53 \pm 0.06 \mathrm{t \dagger}$ & $0.55 \pm 0.08 \mathrm{H \dagger}$ & $<0.0001$ \\
\hline
\end{tabular}

Values are presented as mean $\pm \mathrm{SD} . \dagger \mathrm{p}<0.05 ; \mathrm{\dagger} \mathrm{p}<0.001 ; \mathrm{\dagger}+\mathrm{p}<0.0001 \mathrm{HIV}$ patients (On-treatment and treatment naïve groups) compared to control. 


\section{Conclusion}

From this present study, it was evident that HIV infection is more prevalent among females than males. This present study also established that the pathogenic effect of HIV virus resulted in significantly low mean levels of CD4, CD8, CD4/CD3 and CD4/CD8 ratio among on HAART and HAART naïve patients compared to control group $(\mathrm{p}<0.0001)$.

\section{References}

[1]. Haga T, Efird JT, Tugizov S, Palefsky JM. Increased TNF-alpha and sTNFR2 levels are associated with high-grade anal squamous intraepithelial lesions in HIV-positive patients with low CD4 level. Papillomavirus Res. 2017 Jun;3:1-6. PubMed PMID: 28720441.

[2]. Pasquereau S, Kumar A, Herbein G. Targeting TNF and TNF receptor pathway in HIV-1 infection: from immune activation to viral reservoirs. Viruses. 2017 Mar 30;9(4). PubMed PMID: 28358311.

[3]. Liu L, Tuo HZ, Wang RJ, Yi L, Wang JW, Wang DX. Human cytomegalovirus-IgM seropositivity is not associated with atherogenic alterations of lipid profiles and inflammatory status in ischemic stroke patients: a preliminary study. Neurol Res. 2011 Jun;33(5):473-81. PubMed PMID: 21669115.

[4]. Deeks SG, Kitchen CM, Liu L, Guo H, Gascon R, Narváez AB, Hunt P, Martin JN, Kahn JO, Levy J, McGrath MS. Immune activation set point during early HIV infection predicts subsequent $\mathrm{CD} 4+\mathrm{T}$-cell changes independent of viral load. Blood. 2004 Aug 15;104(4):942-7. PubMed PMID: 15117761.

[5]. Giorgi JV, Lyles RH, Matud JL, Yamashita TE, Mellors JW, et al. Predictive value of immunologic and virologic markers after long or short duration of HIV-1 infection. J Acquir Immune Defic Syndr. 2002 Apr 1;29(4):346-55. PubMed PMID: 11917238.

[6]. Jiang W, Lederman MM, Hunt P, Sieg SF, Haley K, Rodriguez B, et al. Plasma levels of bacterial DNA correlate with immune activation and the magnitude of immune restoration in persons with antiretroviral-treated HIV infection. J Infect Dis. 2009 Apr 15;199(8):1177-85. PubMed PMID: 19265479.

[7]. Hunt PW, Brenchley J, Sinclair E, McCune JM, Roland M, Shafer KP, et al. Relationship between $\mathrm{T}$ cell activation and CD4+ T cell count in HIVseropositive individuals with undetectable plasma HIV RNA levels in the absence of therapy. J Infect Dis. 2008 Jan 1;197(1):126-33. PubMed PMID: 18171295.

[8]. Rodríguez B, Sethi AK, Cheruvu VK, Mackay W, Bosch RJ, et al. Predictive value of plasma HIV RNA level on rate of CD4 T-cell decline in untreated HIV infection. JAMA. 2006 Sep 27;296(12):1498-506. PubMed PMID: 17003398.
[9]. Hazenberg MD, Otto SA, van Benthem BH, Roos MT, et al. Persistent immune activation in HIV-1 infection is associated with progression to AIDS. AIDS. 2003 Sep 5;17(13):1881-8. PubMed PMID: 12960820.

[10]. Rotger M, Dalmau J, Rauch A, McLaren P, Bosinger SE, et al. Comparative transcriptomics of extreme phenotypes of human HIV-1 infection and SIV infection in sooty mangabey and rhesus macaque. J Clin Invest. 2011 Jun;121(6):2391-400. PubMed PMID: 21555857.

[11]. Choudhary SK, Vrisekoop N, Jansen CA, Otto SA, Schuitemaker H, Miede$\mathrm{ma} F$, et al. Low immune activation despite high levels of pathogenic human immunodeficiency virus type 1 results in long-term asymptomatic disease. J Virol. 2007 Aug;81(16):8838-42. PubMed PMID: 17537849.

[12]. Sauce D, Larsen M, Fastenackels S, Pauchard M, Ait-Mohand H, et al. HIV disease progression despite suppression of viral replication is associated with exhaustion of lymphopoiesis. Blood. 2011 May 12;117(19):5142-51. PubMed PMID: 21436070.

[13]. Douek DC, Brenchley JM, Betts MR, Ambrozak DR, et al. HIV preferentially infects HIV-specific CD4+ T cells. Nature. 2002 May 2;417(6884):958. PubMed PMID: 11986671.

[14]. Mandy F, Nicholson J, Autran B, Janossy G. T-cell subset counting and the fight against AIDS: Reflections over a 20-year struggle. Cytometry. $2002 \mathrm{Apr}$ 15;50(2):39-45. PubMed PMID: 12116344.

[15]. Hsue PY, Lo JC, Franklin A, Bolger AF, Martin JN, et al. Progression of atherosclerosis as assessed by carotid intima-media thickness in patients with HIV infection. Circulation. 2004 Apr 6;109(13):1603-8. PubMed PMID: 15023877.

[16]. Gougeon ML, Lecoeur H, Dulioust A, Enouf MG, Crouvoiser M, et al. Programmed cell death in peripheral lymphocytes from HIV-infected persons: increased susceptibility to apoptosis of CD4 and CD8 T cells correlates with lymphocyte activation and with disease progression. J Immunol. 1996 May 1;156(9):3509-20. PubMed PMID: 8617980

[17]. Herbeuval JP, Grivel JC, Boasso A, Hardy AW, Chougnet C, et al. CD4+ T-cell death induced by infectious and noninfectious HIV-1: role of type 1 interferon-dependent, TRAIL/DR5-mediated apoptosis. Blood. 2005 Nov 15;106(10):3524-31. PubMed PMID: 16046522.

[18]. Borges ÁH, O'connor JL, Phillips AN, Rönsholt FF, et al. Factors associated with plasma IL-6 levels during HIV infection. J Infect Dis. 2015 Aug 15;212(4):585-95. PubMed PMID: 25722296.

[19]. Schacker TW, Reilly C, Beilman GJ, Taylor J, Skarda D, Krason D, et al. Amount of lymphatic tissue fibrosis in HIV infection predicts magnitude of HAART-associated change in peripheral CD4 cell count. AIDS. 2005 Dec 2;19(18):2169-71. PubMed PMID: 16284469.

[20]. Schacker TW, Nguyen PL, Beilman GJ, Wolinsky S, Larson M, et al. Collagen deposition in HIV-1 infected lymphatic tissues and T cell homeostasis. J Clin Invest. 2002 Oct;110(8):1133-9. PubMed PMID: 12393849.

[21]. Huang W, De Gruttola V, Fischl M, Hammer S, Richman D, et al. Patterns of plasma human immunodeficiency virus type 1 RNA response to antiretroviral therapy. J Infect Dis. 2001 May 15;183(10):1455-65. PubMed PMID: 11319681. 